\title{
RESEARCH PAPER \\ Colonization of blueberry (Vaccinium corymbosum) plantlets by ericoid mycorrhizae under nursery conditions
}

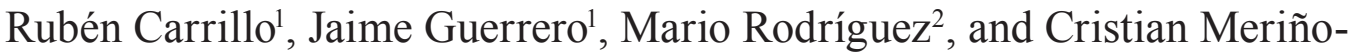 Gergichevich $^{3}$}

${ }^{1}$ Facultad de Ciencias Agropecuarias y Forestales, Universidad de La Frontera, Ave. Francisco Salazar 01145, Casilla 54-D, Temuco, Chile. ${ }^{2}$ Escuela de Agronomía, Facultad de Recursos Naturales, Universidad Católica de Temuco, Casilla 15-D, Temuco, Chile. ${ }^{3}$ Center of Plant, Soil Interaction and Natural Resources Biotechnology, Scientific and Technological Bioresource Nucleus (BIOREN-UFRO), Universidad de La Frontera, Av. Francisco Salazar 01145, Casilla 54-D, Temuco, Chile.

\begin{abstract}
R. Carrillo, J. Guerrero, M. Rodríguez, and C. Meriño-Gergichevich. 2015. Colonization of blueberry (Vaccinium corymbosum L.) plantlets by ericoid mycorrhizae under nursery conditions. Cien. Inv. Agr. 42(3): 365-374. The ericoid mycorrhiza is a symbiotic interaction that contributes to the improvement of the establishment and production of blueberries (Vaccinium corymbosum L.). The objectives of this paper were to assess the frequency (\%) and intensity (\%) of the colonization and growth of blueberry plantlets inoculated with ericoid mycorrhizae collected from three different edaphoclimatic conditions in the La Araucanía region of southern Chile under nursery conditions. Plantlets of three blueberry cultivars ("Brigitta", "Duke" and "Legacy") were grown under nursery conditions in sterile peat moss and a vermiculite substrate with fresh ericoid mycorrhizae propagules from Gaultheria pumila (collected in Villarrica National Park), Azalea sp., (from an urban garden in Temuco) or $V$. corymbosum cv. "Brigitta" (from an organic farm in Temuco). After six months, the development of hyphae characteristic of ericoid micorrhizal fungi was identified in root cells. The frequency and intensity of colonization was greater in the "Duke" cv. given the inoculum derived from $V$. corymbosum, followed by the "Brigitta" and "Legacy" cultivars treated with inoculum from the G. pumila inoculum. Colonization was lowest in those plants treated with the Azalea sp. inoculum. Contact between the inoculum sources and the fine roots of the micro-propagated blueberry plantlets under nursery conditions for six months was an effective method to promote mycorrhization. However, the development of mycorrhizae did not enhance the growth of the three blueberry cultivars during the evaluation period. The possibility of selecting ericoid inocula from site-specific conditions in southern Chile may eventually be used to support the micro-propagation of blueberry plantlets during acclimation and planting, assuming that mycorrhizal plants will improve conditions for establishment in the field.
\end{abstract}

Key words: Blueberry, ericoid mycorrhizae, micorrhizal colonization.

\section{Introduction}

Blueberries (Vaccinium corymbosum L.) are fruit-bearing shrubs of the Ericaceae family and

Received October 30, 2014.Accepted July 15, 2015. Corresponding author: ruben.carrillo@ufrontera.cl originated in North America. This species grows well in acidic soils $(\mathrm{pH} \leq 5.5)$ high in organic matter (OM) and with good drainage (Gough, 1997; Trehane, 2004). Due to Chile's favorable soil and climatic conditions, the area planted with this species has now increased to over 14,000 hectares (ha), making the country a world class producer 
of blueberries during the off-season in the USA, European, and more recently, Asian markets (ODEPA, 2014). However, the increase in supply of exportable fruit from other Southern Hemisphere countries and the rise in production and fertilizer costs have reduced the plant's profitability. As a result, it is necessary to optimize production costs, which often requires the application of nutrition strategies, among other measures, to increase the sustainable use of natural resources while reducing artificial fertilization, and increasing economic and environmental benefits.

In this context, the use of beneficial biological interactions such as mycorrhizal activity offers a natural way of improving plant nutrition and the successful establishment of crops via these biological interactions (Castillo et al., 2008). Beltrano et al. (2013) reported the positive effect of inoculation using arbuscular mycorrhizae fungi (Glomus intraradices) on the growth and functioning of physiological parameters and the absorption of mineral nutrition in bell-pepper (Capsicum annuum L.) plants under different salinity and phosphorus levels, which alleviated the damage caused by salt stress. Moreover, a study by Borie and Rubio (1999) reported an increased tolerance to the presence of phytotoxic aluminum, as well as improved absorption of nutrients such as calcium, magnesium and phosphorus in barley plants (Hordeum vulgare L.) grown in acidic volcanic soils (Borie and Rubio, 1999).

Mycorrhizae are symbiotic associations between soil fungi and the roots of vascular plants. They help to improve the absorption of water and nutrients through an extensive network of hyphae, thereby allowing plants to explore larger volumes of soil (Brundrett, 2002; Pigna et al., 2014). They also stimulate the plant's defense mechanisms against biotic and abiotic stresses (Koron and Gogala, 2000; Castillo et al., 2008). The highbush blueberry has a weak root system; it is superficial, of limited extension and lacks root hairs, facts all of which reduce its ability to uptake water and nutrients. As an introduced species in Chile, this plant's potential for mycorrhization by native mycorrhizae is low (Trehane, 2004; Carrillo, 2013). This presents a significant advantage for the improvement of nutrition in blueberry plants via inoculation at an early growth stage with mycorrhizae from the Ericaceae family, known as ericoid mycorrhizae (Yang et al., 2002), a family that has been little studied in Chile (Vega et al., 2009; Carrillo, 2013). This type of mycorrhizal plant is localized in the fine root systems of subfamilies such as Ericoideae, Vaccinioideae and Rhododendrideae, which belong to the families Ericaceae, Epacridaceae and Empetraceae. It is particularly evident in the genera Rhododendron, Vaccinium, Erica, Gaultheria, Ledum and Kalmia (Sanchez de P., 2007) and is characterized morphologically by a loose net of external hyphae that extend along, between and inside the epidermal cells of the root hairs, without penetrating the membrane, to form coils at different densities within the cells (Bergero et al., 2000), where the mycelium extends $1 \mathrm{~cm}$ beyond the root surface. The duration of this partnership has been shown to last for no more than 11 weeks (Mitchell and Gibson, 2006).

Molecular DNA studies have demonstrated a lack of specificity in mycorrhizal associations, particularly because the same root can hold three or more species of mycorrhizal fungi, and different root systems can be colonized by the same fungal organism. In this regard, ericoid mycorrhizae have been considered the most specific form of mycorrhizae because they colonize a limited number of hosts; however, observations obtained using molecular methods indicate that they may be able to colonize very distant taxa (Bergero et al., 2000; Perotto et al., 2002).

Ericoid mycorrhizal associations are typically present in cold, wet ecosystems where no atmospheric nitrogen fixation via bacterial processes occurs because of the low $\mathrm{pH}$ in the soil. In these environments, the terrain is generally rich in organic substances that decompose slowly. The mycelia of these fungi extend themselves through 
the soil via the secretion of proteolytic enzymes, which hydrolyze proteins present in the soil, reducing the proteins to absorbable compounds such as amino acids and polypeptides and producing nitrogen compounds. Thus, this partnership enables the colonization of extremely poor habitats with a high mineral content and/or climatically challenging environments, and, under certain conditions, it is essential for the survival of the plant (Dixon, 2002).

Molina et al. (2005) indicate that mycorrhizae in host plants kept under controlled conditions, such as in a greenhouse or during plant rooting in vitro, help micro-propagated plantlets to root and acclimate after transplanting by increasing the size of the root system and stimulating epigeal growth. Various studies related to the inoculation of blueberries using ericoid mycorrhizae exist, both under field and nursery conditions (Eccher and Noé, 2002; Noé et al., 2002; Starrett, 2003; Waters et al., 2008). It has been found that this symbiotic association improves the growth and survival of individual plants in the nursery, while reducing the need for nutrients from supplementary fertilization (Koron and Gogala, 2000; Scagel, 2005). In Chile, highbush blueberries have been treated with a mycorrhizal inoculum imported from the USA with limited success because the mycorrhizal interaction is less than optimum in the southern Chilean soil and climate (Vega et al., 2009). Therefore, we set out to perform an applied study using mycorrhizal inocula originating locally at sites associated with endemic plants of the Ericaceae family, in which this type of natural mycorrhization has been documented but not identified at the species level (Carrillo et al., 1992; Vega and Muñoz, 1994). The aim of this study was to evaluate the frequency and intensity of the colonization and growth of the stems and roots of different blueberry plantlet cultivars ("Brigitta", "Duke" and "Legacy") inoculated in a nursery with three different ericoid micorrhizae collected from separate locations in the La Araucanía region.

\section{Materials and methods}

\section{Study site and inocula sources}

This study was conducted in the Maranello nursery in Nacimiento ( $37^{\circ} 30^{\prime} \mathrm{S}, 72^{\circ} 40^{\prime} \mathrm{W}$ ), Bío Bío Region and at the Universidad de La Frontera, Temuco, La Araucanía Region, Chile. Propagules of ericoid mycorrhizae used to inoculate host blueberry plantlets were obtained from the following inocula sources (IS): chaura (Gaultheria pumila (L. f.) Middleton) ( eight years-old), collected in Villarrica National Park $\left(39^{\circ} 20^{\prime} \mathrm{S}, 71^{\circ} 22^{\prime} \mathrm{W}\right)$; azalea (Azalea $\mathrm{sp}$.), from a traditional urban garden in the city of Temuco ( five years-old); and blueberry cv. Brigitta (four years-old), collected from an organic farm in Temuco $\left(38^{\circ} 45^{\prime} \mathrm{S}, 72^{\circ} 40^{\prime} \mathrm{W}\right)$. Three well developed plants from each IS were utilized and processed according to the method proposed by Steubing et al. (2002). The ericoid mycorrhizal fungi obtained from each IS plant were identified morphologically on the basis of formed hyphal structures in the epidermal cells of hair roots, and dark septate endophitic mycorrhiza were detected in the sampled hair roots via microscopy (Tian et al., 2011). The foliage was cut off of each plant selected as an inoculum source; after five weeks, the soil around the plant was carefully removed, and the roots were trimmed to a length of 0.5 to $1 \mathrm{~cm}$. Each inoculum was prepared by mixing soil and root pieces from each IS plant with an acidified vermiculite:peatmoss substrate (S) (1:1 $\mathrm{v} / \mathrm{v}$ ) over three months. The following inocula were used for evaluation: chaura ( $\mathrm{S}+\mathrm{RC})$, azalea $(\mathrm{S}+\mathrm{RA})$, blueberry $(\mathrm{S}+\mathrm{RB})$ and a non-inoculated sterile peat moss (control). Evaluations were done following the procedure in Brundrett et al. (1996).

\section{Inoculation of blueberry plantlets}

For each cultivar ("Brigitta", "Duke" and "Legacy"), a total of sixty micro-propagated blueberry plantlets (30 days old) were inoculated (20 plantlets 
per inoculum) and then planted in polyurethane propagation trays (each tray was a replicate) so that the root of each plant came into direct contact with the inoculum. Each inoculum consisted of a separate mixture of root fragments $(10 \mathrm{~g})$ from each IS and $15 \mathrm{~g}$ of a sterile vermiculite:peatmoss $(1: 1 \mathrm{v} / \mathrm{v})$ mixture. The control treatment consisted of a sterile vermiculite:peatmoss mixture $(25 \mathrm{~g})$ without mycorrhizae ( $\mathrm{pH}$ 5.0). The inoculated plantlets were maintained under similar environmental conditions, with no fertilization of the substrate either at transplantation or subsequently. Each plantlet was watered as needed with distilled water to keep the substrate moist but not saturated. Plantlets were kept in propagation trays in a growing chamber $\left(23^{\circ} \mathrm{C} \pm 2^{\circ} \mathrm{C}, 80 \% \mathrm{RH}\right)$ for six months; with a photoperiod of $16 \mathrm{~h}$ light $/ 8 \mathrm{~h}$ darkness. The photosynthetic active radiation (PAR) was $300 \mu \mathrm{mol} \mathrm{m} \mathrm{m}^{-2} \mathrm{~s}^{-1}$. This length of time is commonly used in commercial nurseries for rooting plantlets prior to definitive establishment in the field.

\section{Measuring growth in inoculated plantlets}

To assess each plantlet's condition prior to transplanting in the field, the following morphometric parameters were recorded after six months: shoot length (LS), root length (LR) and the crown diameter (CD) of the shoot and the root. The fresh and dry weights of the shoots (FWS, DWS) and roots (FWR, DWR) were measured using a digital balance. To determined he dry weight (DW), the roots and shoots were gently cleaned and put in separate, labelled porous bags in a drying oven $\left(60^{\circ} \mathrm{C}\right.$ in 410 Memmert, Schwabach, Germany) until they reached constant DW.

Measuring root colonization by ericoid mycorrhizal fungi

The fresh roots of the plantlets were cut into $1 \mathrm{~cm}$ long fragments, stained with $0.05 \%$ aniline blue dye and placed in a reticulated Petri dish (Phillips and Hayman, 1970). The line intercept method was used to determine the presence of fungal structures such as mycelia, spores and intraradical vesicles. These structures were counted under a stereoscopic microscope (40X), and the results were expressed as the colonization frequency $(\%)$ and intensity (\%) in fresh roots compared to the non-inoculated control.

\section{Statistical analysis}

The experimental design was completely randomized, with three replicates per treatment. Once the normality of the data was assessed, an analysis of variance (ANOVA) was conducted for all studied variables. The mean growth parameters were analyzed using an orthogonal contrast, and Tukey's test was applied to assess the degree of mycorrhizal colonization $(\mathrm{P} \leq 0.05)$.

\section{Results and discussion}

Frequency and intensity of mycorrhization by inoculum sources

To determine the presence of ericoid mycorrhizae in the roots of the plants used as ISs, the frequency and intensity of mycorrhizal colonization was measured (Table 1). It was found that G. pumila and $V$. Corymbosum showed higher colonization frequencies and intensities than Azalea sp., with mean differences of 20 and $71 \%$, respectively. The Azalea sp. specimens may have lower colonization rates because they were taken from plants grown ornamentally in an urban environment, and under this condition, there is less of a possibility of encountering ericoid mycorrhiza propagules. The differences among ISs can also be explained by the origin of the soil and the specific environments in which the inoculum source plants grew. In the case of the inoculum developed from $V$. corymbosum, it was assumed that the greater mycorrhization resulted from the organic treatments applied to the crop, which conditioned the plants 
to develop a strengthened symbiotic association with the mycorrhizae, thereby allowing the roots to meet the demands for water and nutrients more efficiently. In the case of G. pumila, the development of the inoculum source plant in an environment with natural co-evolution was thought to result in a specific symbiotic relationship that allowed stronger endemic mycorrhization.

\section{Growth of inoculated plantlets}

The morphometric parameters evaluated in the inoculated plants and the controls for each cultivar are presented in Table 2. The ISs had no effect on FWS, DWS, FWR or DWR, either in the shoots or roots of the three cultivars. However, in the shoot:root ratio for the three cultivars, the growth differential between inoculated and non-inoculated plants was smaller than that of the control, from which we can deduce that the mycorrhizae favored the growth of roots above the shoots. This may be attributable to the specific interaction produced between the mycorrhizae and the roots of the host plant. It may also be inferred that the experimental conditions restricted the growth-strengthening
Table 1. Degree of ericoid colonization measured as frequency (\%) and intensity (\%) of plant root colonization by inoculum source (IS)

\begin{tabular}{lcc}
\hline Inoculum source (IS) & Frequency (\%) & Intensity (\%) \\
\hline Azalea sp. & 72.66 & 12.35 \\
Gaultheria pumila & 90.33 & 44.79 \\
Vaccinium corymbosum & 89.66 & 40.53
\end{tabular}

Frequency (\%) and intensity (\%) percentages are expressed as the average of 30 measurements taken per IS.

expression of the mycorrhizae (Table 2). Molina et al. (2005) reported that the effectiveness of inoculation is extremely variable and depends on multiple eco-physiological factors present in the interaction between plant and soil; as a result, the same inoculum may impact different plants in different ways, and plant responses cannot be safely generalized by species across varying ecosystems.

The S+RA treatment provoked an increase in LR in the Legacy cultivar $(\mathrm{P} \leq 0.05)$, but no other significant differences in LR were identified in relation to the other inocula evaluated in any of the cultivars (Table 2). For aerial biomass, $\mathrm{CD}$ and root biomass, no significant differences were detected between the cultivar treatments or between the treatments and

Table 2. Comparison of mean morphometric parameters to a control in blueberry cultivars inoculated with different ericoid mycorrhizae obtained from V. corymbosum, Azalea sp. and G. pumila.

\begin{tabular}{|c|c|c|c|c|c|c|c|c|}
\hline \multirow[b]{2}{*}{ Cultivar } & \multicolumn{5}{|c|}{ Weight (g) } & \multicolumn{3}{|c|}{ Length $(\mathrm{cm})$} \\
\hline & IS & FWS & DWS & FWR & DWR & LS & LR & $\mathrm{CD}$ \\
\hline \multirow[t]{4}{*}{ Brigitta } & Control & 0.80 & 0.25 & 0.30 & 0.07 & 14.66 & 8.00 & 2.60 \\
\hline & $\mathrm{S}+\mathrm{RB}$ & $0.28^{1}$ & $0.10^{1}$ & 0.30 & 0.06 & 12.16 & 7.33 & $1.16^{1}$ \\
\hline & $\mathrm{S}+\mathrm{RA}$ & $0.44^{1}$ & $0.13^{1}$ & 0.40 & 0.07 & 14.33 & 8.66 & 1.83 \\
\hline & $\mathrm{S}+\mathrm{RC}$ & $0.44^{1}$ & $0.08^{1}$ & 0.10 & $0.03^{1}$ & $10.83^{1}$ & 6.66 & 1.56 \\
\hline \multirow[t]{4}{*}{ Duke } & Control & 0.57 & 0.15 & 0.30 & 0.06 & 12.13 & 8.00 & 1.83 \\
\hline & $\mathrm{S}+\mathrm{RB}$ & $0.18^{1}$ & $0.06^{1}$ & 0.20 & 0.05 & $8.00^{1}$ & 8.50 & $0.93^{1}$ \\
\hline & $\mathrm{S}+\mathrm{RA}$ & $0.29^{1}$ & 0.08 & 0.20 & 0.05 & $8.66^{1}$ & 7.83 & 1.16 \\
\hline & $\mathrm{S}+\mathrm{RC}$ & $0.18^{1}$ & $0.06^{1}$ & 0.20 & 0.04 & $9.00^{1}$ & 8.33 & 1.10 \\
\hline \multirow[t]{4}{*}{ Legacy } & Control & 0.70 & 0.29 & 0.70 & 0.15 & 15.95 & 7.55 & 2.20 \\
\hline & $\mathrm{S}+\mathrm{RB}$ & 0.54 & 0.21 & 0.40 & 0.10 & 16.16 & 8.16 & 1.66 \\
\hline & $\mathrm{S}+\mathrm{RA}$ & 0.51 & $0.17^{1}$ & 0.40 & 0.13 & 14.00 & $11.00^{1}$ & 1.50 \\
\hline & $\mathrm{S}+\mathrm{RC}$ & $0.36^{1}$ & $0.13^{1}$ & $0.36^{1}$ & 0.13 & $13.00^{1}$ & 7.25 & $1.33^{1}$ \\
\hline
\end{tabular}

IS, Inoculum source; FWS, fresh weight of shoots; DWS, dry weight of shoots; FWR, fresh weight of roots; DWR, Dry weight of roots; LS, length of stem; LR, length of root; and CD, crown diameter.

${ }^{1}$ Indicates significant differences among treatments for the same cultivar according to orthogonal contrasts $(\mathrm{P} \leq 0.05)$.

$\mathrm{S}+\mathrm{RB}$ Inoculum from $V$. corymbosum, $\mathrm{S}+\mathrm{RA}$ inoculum from Azalea sp. and $\mathrm{S}+\mathrm{RC}$ inoculum from $G$. pumila. 
the control for each cultivar. This result is similar to that reported by Starrett (2003), who observed greater initial growth and development in the stems of micro-propagated blueberry plants after inoculation with ericoid mycorrhizae isolated from plants of the Ericaceae family. Nevertheless, even though no morphometric effects were detectable with the methodology used, mycorrhization begins in the acclimatization period; hence, it is important to inoculate blueberry plantlets with mycorrhizae during propagation. Roveda et al. (2007) used arbuscular micohrrizae and found that satisfying a plant's demand for photosynthates in this stage of development results in benefits during growth after planting since colonization of the roots by the fungus can stimulate radical biomass growth more intensely at the cost of aerial biomass.

\section{Degree of ericoid mycorrhizal colonization in inoculated cultivars}

Six months after inoculation, mycorrhizal colonization was found in all the three cultivars for all three IS treatments. Colonization was indicated by the characteristic presence of round bundles of ericoid mycorrhizae hyphae inside the root cells of the inoculated blueberry plants (Figure 1). The conformation of the fungi coincided with the morphometric aspects described for reference by various authors (Bergero et al., 2000; Perotto et al., 2002). Tian et al. (2011) states that to accurately identify the effectiveness of the mycorrhizae applied, colonization by the mycorrhizal fungi in the roots must be quantified and characterized; Figure 1 shows the colonization rates obtained in this research.

The frequency and intensity of colonization varied significantly between the cultivars (Table 3). The most effective colonization occurred in the "Duke" cultivar, with frequency rates of $49.8 \%$ and intensity rates of $7.8 \%$. These values were greater than those in "Legacy" cultivar, which exhibited a frequency of $40 \%$ and intensity of $3.6 \%(\mathrm{P} \leq 0.05)$. Intermediate colonization values were recorded for the "Brigitta" cultivar. The numerical results were

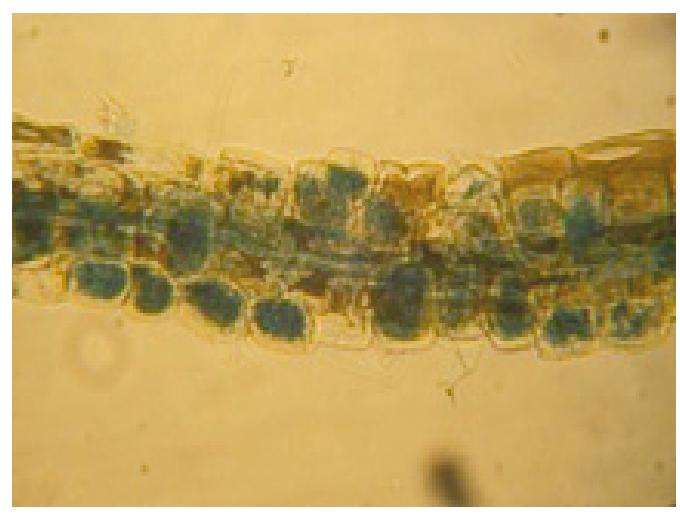

Figure 1. Ericoid hyphae bundles inside epidermal cells of inoculated blueberry cultivar roots. Aniline blue stained. 40x.

higher than those recorded by Scagel (2005), who measured between 15 and $30 \%$ colonization two years after the inoculation of 6-week-old blueberry plants. The frequency obtained in highbush blueberry cultivars was similar to that obtained in a tissue culture from blackberry (Rubus sp.) plants inoculated at the acclimatization stage with a native inoculum of vesicular arbuscular mycorrhizae; in that study, a colonization frequency of $40 \%$ was considered high (Roveda et al., 2007).

In the individual blueberry cultivars inoculated with $\mathrm{S}+\mathrm{RB}$ and $\mathrm{S}+\mathrm{RC}$, colonization was significantly higher than that detected in plants inoculated with $\mathrm{S}+\mathrm{RA}(\mathrm{P} \leq 0.05$; Table 3$)$. In studies carried out in the USA, high colonization was achieved when

Table 3. Degree of ericoid colonization of blueberry cultivars and inocula used to treat plants.

\begin{tabular}{ccc}
\hline & \multicolumn{2}{c}{ Colonization } \\
\cline { 2 - 3 } & $\begin{array}{c}\text { Frequency } \\
(\%)\end{array}$ & $\begin{array}{c}\text { Intensity } \\
(\%)\end{array}$ \\
\hline Cultivar & & \\
Brigitta & $44.9 \mathrm{ab}$ & $5.4 \mathrm{~b}$ \\
Duke & $49.8 \mathrm{a}$ & $7.8 \mathrm{a}$ \\
Legacy & $40.0 \mathrm{~b}$ & $3.6 \mathrm{~b}$ \\
Inoculum & & \\
S+RB & $50.2 \mathrm{a}$ & $8.2 \mathrm{a}$ \\
S+RA & $32.0 \mathrm{~b}$ & $2.2 \mathrm{~b}$ \\
S+RC & $52.4 \mathrm{a}$ & $6.4 \mathrm{a}$ \\
\hline
\end{tabular}

Different letters indicate significant differences based on the Tukey test $(\mathrm{P} \leq 0.05)$.

$\mathrm{S}=$ substrate, $\mathrm{RA}=$ Azalea $\mathrm{sp}$. root, $\mathrm{RB}=V$. corymbosum root, and $\mathrm{RC}=$ G. pumila root. 
inoculated blueberry cultivars were grown in a nursery with isolated symbiotic fungi from the roots of V. corymbosum (Read, 1991). This result shows the specific interaction of the local ericoid mycorrhizal fungus with blueberry plants, which is the product of successful co-evolution (Scagel, 2005). The consistent colonization found by using $\mathrm{S}+\mathrm{RC}$ and soil may be explained by the fact that the mycorrhizal fungi that develop in plants of this species have been subjected to a variety of extreme abiotic stresses related to climate and soil over several years. As a result, this species of native ericoid mycorrhiza continuously generates active propagules which are very efficient colonizers. Consensus on this point supports the idea that these symbiotic mycorrhizal fungi have adapted to a wide range of habitats and soil types in both the Northern and Southern Hemispheres. Mitchell and Gibson (2006) also note that it is this association, to a large extent, that allows plants to develop in different environmental conditions, including thin soils where roots cannot penetrate deeper than $10 \mathrm{~cm}$.

Colonization was highest in the "Duke" cultivar treated with $\mathrm{S}+\mathrm{RB}$, both in terms of frequency $(65 \%)$ and intensity (15\%). These values were significantly higher than those obtained via the S+RA inoculation in all three cultivars and the $\mathrm{S}+\mathrm{RB}$ treatment in the "Legacy" cultivar (Table 4). Vega et al. (2009) reported a similar result when the blueberry cultivar, O'Neil, was inoculated with an endemic inoculum derived from the Pernettya sp. (now Gaultheria sp.) roots taken from an Andean volcanic ash soil ( $38^{\circ}$ 30 ’ S; pH 5.8). In North America, 70 to $100 \%$ natural colonization is recorded in ericaceous species; in commercial blueberry orchards in Oregon (USA), 0.5 to $44 \%$ colonization has been recorded in a range of cultivars, whereas in Finland, 48\% colonization has been found in native blueberries (Scagel et al., 2005). In Chile, average frequencies of $53.6 \%$ and intensities of $2.9 \%$ were reported in a 5 -year-old non-inoculated commercial blueberry orchard in the Bío Bío Region (Carrillo et al., 2009),while research by Vega and Muñoz (1994) reported similar colonization levels to those found in the present study in non-inoculated micro-propagated blueberry plants (sixth leaf) established in commercial plantations. The mycorrhization results obtained in the cultivars evaluated (Duke, Brigitta and Legacy) permit the inference that the propagules in the three substrates used for inoculation were capable of colonizing the plants but that the intensity of colonization differs among the blueberry cultivars.

Table 4. Degree of interaction between ericoid colonization and blueberry cultivars with different inocula obtained from $V$. corymbosum, Azalea sp. and G. pumila.

\begin{tabular}{lcc}
\hline Cultivar & $\begin{array}{c}\text { Inoculum } \\
\text { Source }\end{array}$ & $\begin{array}{c}\text { Frequency- Intensity } \\
(\%)\end{array}$ \\
\hline Brigitta & S+RB & $53.3-6.8 \mathrm{ab}$ \\
& S+RA & $26.6-1.6 \mathrm{~d}$ \\
\multirow{2}{*}{ Duke } & S+RC & $54.6-7.5 \mathrm{ab}$ \\
& S+RB & $65.3-15.3 \mathrm{a}$ \\
\multirow{3}{*}{ Legacy } & S+RA & $30.6-1.8 \mathrm{~d}$ \\
& S+RC & $53.3-6,1 \mathrm{ab}$ \\
& S+RB & $32.0-2.4 \mathrm{~cd}$ \\
& S+RA & $38.6-3.4 \mathrm{bcd}$ \\
\hline
\end{tabular}

Different letters indicate significant differences based on the Tukey test $(\mathrm{P} \leq 0.05)$. $(\mathrm{S}+\mathrm{RB})$ Inoculum from $V$. corymbosum, (S+RA) inoculum from Azalea sp., and (S+RC) inoculum from G. pumila.

Colonization was less effective in the case of the $\mathrm{S}+\mathrm{RA}$ inoculum, which may be explained by the poor specificity of this strain, despite the fact that the frequency (72.6\%) and intensity (12.3\%) of colonization by S+RA in the Duke, Brigitta and Legacy cultivars was considered to be mediumhigh (Table 2). The other inocula resulted in mycorrhization frequency and intensity rates greater than those found for the azalea inoculum; G. pumila had a colonization frequency of $90.3 \%$ and intensity of $44.8 \%$, while $V$. corymbosum had a frequency of $89.6 \%$ and intensity of $40.5 \%$. Scagel et al. (2005) reported that the low availability of propagules diminished the colonization potential of ericoid mycorrhizae, and it may be that this was the case for the Azalea sp. propagules.

Ericoid mycorrhizae hyphae developed in a bell shape in the root cells of micro-propagated blueberry plantlets acclimated in a nursery; and the frequency and intensity of colonization was higher 
in the Duke cv. given the blueberry inoculum, followed by Brigitta and Legacy given the $G$. pumila inoculum. Lower colonization rates were observed in plants given the Azalea sp. inoculum. The inocula sources were maintained in a peat moss and vermiculite substrate for three months prior to contact with blueberry roots, which occurred continuously for six months after planting under nursery conditions. This effort revealed effective mycorrhizal colonization; however, it did not enhance the growth of the three blueberry cultivar plantlets during the evaluation period. It is expected that the mycorrhizae-treated plantlets would be better prepared for establishment under field conditions, particularly since plants that have established a symbiotic interaction with strains of ericoid mycorrhizae have more effective competitive potential and a better chance of overcoming abiotic stress.

\section{Acknowledgements}

The authors wish to thank DIUFRO Project $\mathrm{N}^{\mathrm{o}}$ 2028, Dirección de Investigación; Universidad de La Frontera; Innova BíoBío CORFO 06-IES1-106; Vivero Maranello, Los Ángeles, Chile.

\title{
Resumen
}

\begin{abstract}
R. Carrillo, J. Guerrero, M. Rodríguez y C. Meriño-Gergichevich. 2015. Colonización de plántulas de arándano (Vaccinium corymbosum) en condiciones de vivero por micorrizas ericoides. Cien. Inv. Agr. 42(3): 365-374. La micorrización ericoide es una interacción simbiótica que contribuye a mejorar el establecimiento y producción de arándano (Vaccinium corymbosum L.). Los objetivos fueron evaluar frecuencia (\%) e intensidad (\%) de colonización, y crecimiento de plántulas de arándano inoculadas en vivero con micorrizas ericoides colectadas desde tres condiciones edafoclimáticas en la Región de La Araucanía, Chile. En condiciones de invernadero, plántulas de tres cultivares de arándano fueron establecidas en sustrato de turba estéril y vermiculita mezclada con propágulos frescos de micorrizas ericoides provenientes de Gaultheria pumila (Parque Nacional Villarrica) Azalea sp., (Jardín Ornamental en Temuco)y de $V$. corymbosum cv "Brigitta" (plantación orgánica en Temuco). Trascurrido seis meses, se constató en células de raíces finas el desarrollo de hifas en forma de ovillo característico de hongos micorrícicos ericoides, cuya frecuencia e intensidad de colonización fue mayor en el cv. Duke con inóculo de V. corymbosum, seguido de "Brigitta" y "Legacy" con inóculo de G. pumila, en tanto que la colonización fue menor con inóculo de Azalea sp., el contacto de las fuentes de inóculo con raicillas de plántulas de arándano micropropagadas en vivero durante seis meses, fue una opción de micorrización eficaz; no obstante y como era esperable no se detectó efecto en el crecimiento de las plántulas de los tres cultivares de arándano durante el periodo de evaluación. La posibilidad de utilizar inóculos ericoides obtenidos de plantas ericáceas del sur de Chile, sería una opción eficaz de micorrización para mejor aclimatación y establecimiento de arándano en diferentes condiciones de campo.
\end{abstract}

Palabras clave: Arándano, colonización micorrícica, micorrizas ericoides.

\section{References}

Beltrano, J., M. Ruscitti, M.C. Arango, and M. Ronco. 2013. Effects of arbuscular mycorrhiza inoculation on plant growth, biological and physiological parameters and mineral nutrition in pepper grown under different salinity and P levels. J. Soil Sci. Plant Nutr.13: 123-141.
Bergero, S., S. Perotto, M. Girlanda, G.Vidano, and A. Luppi. 2000. Ericoid mycorrhyzal fungi are common root associates of a Mediterranean ectomycorrhyzal plant (Quercus ilex). Mol. Ecol. 9: 1639-1669.

Brundrett, M. 2002. Coevolution of roots and mycorrhizas of land plants. New Phytol. 154: $275-$ 304. 
Brundrett, M., M. Bougher, B. Dell, T. Grove, and N. Malajczuc. 1996. Working with mycorrhizae in forestry and agriculture. Australian Centre for International Agricultural Research. 374 pp.

Borie, F., and R. Rubio. 1999. Effects of arbuscular mycorrhizae and liming on growth and mineral acquisition of aluminum-tolerant and aluminumsensitive barley cultivars. J. Soil Sci. Plant Nutr. 22: 121-137.

Carrillo, L.R. 2013. Micorrizas en arándano. p. 171198. In: El arándano en Chile. Ediciones Universidad Católica de Temuco. Temuco, Chile. 321 pp.

Carrillo, R., R. Godoy, and H. Peredo. 1992. Simbiosis micorrícica en comunidades boscosas del Valle Central en el sur de Chile. Bosque 13: 57-67.

Carrillo, R., J. Medina, and M. Rodríguez.2009. Colonización micorrícica en especies endémicas de la familia Ericaceae; Gaultheria pumila (L. Fil) Middleton, Gaultheria mucronata (L. Fil) Gaud. Ex Spreng., presentes en tres ecosistemas naturales de la Región de la Araucanía. VII Simposio de Recursos Genéticos para América Latina y el Caribe. Tomo II.

Castillo, C., I. Astroza, F. Borie, and Rubio, R. 2008. Efecto de cultivos hospederos y no hospederos sobre propágulos micorrícicos arbusculares. J. Soil Sci. Plant Nutr. 8: 37-54.

Dixon, K. 2002. Ericoid mycorrhizal in plant communities.p. 227-239. In:K. Sivasithamparam, K. Dixon, and R. Barret (eds.). Microorganisms in plant Conservation and Biodiversity.Kluwer Academic Publishers. New York.

Eccher, T., and N. Noé. 2002. Influence of ericoid endomycorrhizae inoculated in vitro on rooting and early growth of micropropagated plants of Vaccinium corymbosum L. ActaHortic. 574: 373378.

Gough, R. E. 1997. Blueberries-North and South. Journal of Small Fruits and Viticulture 4: 71-106.

Koron, D., and N. Gogala. 2000. The use of mycorrhizal fungi in the growing of blueberry (Vaccinium corymbosum L.). ActaHortic. 525: 101-106.

Mitchell, D., and B. Gibson. 2006. Ericoid mycorrhizal association: Ability to adapt to a broad range of habitats. Mycologist 20: 2-9.
Molina, M., L. Mahecha, and M. Medina. 2005. Importancia del manejo de hongosmicorrizógenos en el establecimiento de árboles en sistemas silvopastoriles. Revista Colombiana de Cs. Pecuarias 18: 162-175.

Noé, N., T. Eccher, and M. Borra.2002. The use of selected mycorrhizae for quality improvement of highbush blueberry (Vaccinium corymbosum L.) plant production. Acta Hortic. 574: 387-392.

ODEPA. 2014. Boletín de insumos.Oficina de Estudios y Estadísticas Agropecuarias, Gobierno de Chile, Santiago, Chile. Available online at: http:// www.odepa.gob.cl (Website accessed: September 11, 2014).

Perotto, S., M. Girlanda, and E. Martino. 2002. Ericoid mycorrhizal fungi: Some new perspectives on old acquaintances. Plant Soil 244: 41-53.

Phillips, J., and D. Hayman.1970. Improved procedures for clearing roots and staining parasitic and vesicular-arbuscular mycorrhizal fungi for rapid assessment of infection. Trans. Br. Mycol. Soc. 55: 158-161.

Pigna, M., A.G. Caporale, P. Cartes, V. Cozzolino, M. Mora, A. Sommella, and A.Violante. 2014. Effects of arbuscular mycorrhizal inoculation and phosphorus fertilization on the growth of escarole (Cichorium endivia L.) in an arsenic polluted soil. J. Soil Sci. Plant Nutr.14: 199209.

Read, D.J. 1991. Mycorrhizas in ecosystems. Experientia 47: 376-390.

Roveda, G., L. Cabra, M. Ramírez, and A. Peñaranda. 2007. Efecto de las micorrizas arbusculares sobre la aclimatación y endurecimiento de microplántulas de mora (Rubus glaucus). Revista Corpoica - Ciencia y Tecnología Agropecuaria 8: 28-36.

Sánchez de P., M. 2007. Endomicorrizas, expresión bioedáfica de importancia en el trópico: Las micorrizas, estrategia compartida para colonizar el suelo. Feriva Cali. Colombia. 351 pp.

Scagel, C., A. Wagner, and P. Winiarsks. 2005. Frequency and intensity of root colonization by ericoid mycorrhizal fungi in nursery production of blueberry plant. Small Fruits Review 4: 95112. 
Scagel, C. 2005. Inoculation with ericoid mycorrhizal fungi alters fertilizer use of highbush blueberry cultivars. Hort Science 40: 786-794.

Starrett, M.C. 2003. Initial shoot growth and development of micropropagated blueberry plants following inoculation with and ericoid mycorrhizal isolate. Acta Hortic. 626: 191-197.

Steubing, L., R. Godoy, and M. Alberdi. 2002. Métodos de Ecología Vegetal. Ed. Universitaria. Santiago, Chile. 345 pp.

Tian, W., C. Q. Zhang, P. Quiao, and R. Milne. 2011. Diversity of culturable ericoid mycorrhizal fungi of Rhododendrum decorum in Yunnan, China. Mycologia 103: 703-709

Trehane, J. 2004. Blueberries, Cranberries and other Vaccinium: Northern highbush blueberries. Royal Horticultural Society. Oregon, USA. 256 pp.
Vega, A., and C. Muñoz. 1994. Presencia de micorrizas en ericáceas en Chile. Agricultura Técnica 54: 332-339.

Vega, A., M. Garciga, A. Rodríguez, L. Prat, and J. Mella. 2009. Blueberries mycorrhizal symbiosis outside of the boundaries of natural dispersion for Ericaceous Plants in Chile. Acta Hortic.810: 665671.

Waters, E., C.Scagel, and C.McLean.2008. A survey of Vaccinium cultural practices in Australia emphasizing implications for mycorrhizal infection. Int. J. Fruit Sci. 8: 109-124.

Yang, W. Q., B. L. Goulart, K. Demchak, and Y. Li. 2002. Interactive effects of mycorrhizal inoculation and organic soil amendments on nitrogen acquisition and growth of highbush blueberry. J. Amer. Soc. Hort. Sci. 127: 742-748. 